\title{
Ortaöğretim Öğrencilerinde Okul Terki Riskinin Yordayıcıları: Okula Bağlılık ve Okul Tükenmişliği
}

\begin{tabular}{lccc}
\hline MAKALE TÜRÜ & Başvuru Tarihi & Kabul Tarihi & Yayım Tarihi \\
Araştırma Makalesi & 02.01 .2020 & 29.03 .2021 & 19.05 .2021 \\
\hline
\end{tabular}

\section{Arif Arslan}

Hacettepe Üniversitesi

Öz

$\mathrm{Bu}$ araştırmada ortaöğretim öğrencilerinin okulu terk etme riskleri; okula bağl1lık, okul tükenmişliği, cinsiyet, daha önce bir işte çalışma durumu, süreğen hastalık, okuldan kaçma ve okul türü değiş̧kenleri açısından incelenmiştir. Araştırma, korelasyonel desene dayanmaktadır. Araştırmanın örneklemini oluşturan 420 ortaöğretim öğrencisi belirlenirken uygun örnekleme yöntemi kullanılmıştır. Yaş ortalaması 15.4 olan 420 öğrencinin 237'si (\%56.4) kadın, 183'ü (\%43.6) erkektir. Veriler analiz edilirken; Pearson korelasyon analizi, çoklu regresyon analizi, t-testi kullanılmıştır. Yapılan analizler sonucunda; okul terki riski ile okula bağlılık arasında negatif yönde anlamlı bir ilișki $(r=-.47, p<.05)$ ve okul terki riski ile okul tükenmișliği arasında ise pozitif yönde anlamlı bir ilişki olduğu $(r=.52, p<.05)$ bulunmuştur. Yapılan çoklu regresyon analizi sonucunda okula bağlılık ve okul tükenmişliğinin, okul terki riskindeki toplam varyansın \%35'ini açıkladığı görülmektedir. Cinsiyeti erkek olan, daha önce bir işte çalışan ve sık sık okuldan kaçan ortaöğretim öğrencilerinin okulu terk etme risklerinin diğer gruptaki öğrencilerden daha yüksek olduğu sonucuna ulaşılmıştır. Sonuç olarak okul terki riskini etkileyen birçok etkenin (faktörün) olduğu görülmektedir. Yapılacak önleme çalıșmalarında bu durumların göz önünde bulundurularak hareket edilmesi daha etkili sonuçlar alınmasını sağlayabilir.

Anahtar sözcükler: Okul terki, okula bağl1lık, okul tükenmişliği, ortaöğretim öğrencileri.

Etik Kurul Kararı: Bu araştırma, 01.01.2020 tarihinden önce yapıldığı için etik kurul kararı zorunluluğu taşımamaktadır.

${ }^{1}$ Sorumlu Yazar: Arş. Gör., Eğitim Fakültesi, Eğitim Bilimleri Bölümü, Rehberlik ve Psikolojik Danıșmanlık Anabilim Dalı, e-posta: arif.arslan@hacettepe.edu.tr, https://orcid.org/0000-0002-50251655 
Derslerin içeriğinden öğretim tekniklerine, okulların işlevinden öğrencilerin eğitimdeki konumuna birçok konu hemen her ülkede eğitimle ilgili tartışılan konulardır. Tartışılan bu konulardan biri de okul terkidir. Ülkelerin eğitim vizyonları doğrultusunda okul terki tanımı farklılık gösterse de bu durumun önemli bir sorun olduğu Amerika Birleşik Devletleri, Hindistan, İtalya, Bulgaristan, Romanya, Türkiye gibi birçok ülke tarafından kabul edilmektedir. Gerek uluslararası gerek ulusal düzeyde alınan önlemlere ve okul terkiyle ilgili yapılan bilimsel araştırmalara karşın birçok ülkede okul terki önemli bir sorun olarak varlığını devam ettirmektedir. Özellikle Güney Asya ve Afrika ülkelerinde okul çağında olup okula gitmeyen öğrenci sayısının oldukça yüksek olduğu görülmektedir (Marphatia, Reid ve Yajnik, 2019). Örneğin, Hindistan'da 12 milyon ilköğretim öğrencisinin okulun dışında olduğu tahmin edilmektedir. Amerika Birleşik Devletleri'nde okul terki oranları \%712 arasında değişmektedir (National Center for Education Statistics-NCES, 2015). Avrupa Birliği'ne üye ülkelerin okul terki oranlarının ortalaması \%10 iken bu oran Türkiye'de \%30 dolayındadır (European Statistical Office-EUROSTAT, 2020). Bu verilerden hareketle Türkiye'de okul terki oranlarının Avrupa Birliği'ne üye ülkelerle karşılaştırıldığında oldukça yüksek olduğu söylenebilir. Nitekim Avrupa Komisyonu (2020) tarafından hazırlanan ilerleme raporlarında Türkiye ile ilgili okul terki oranın azaltılması ve okullaşma oranlarının artırılmasına yönelik çeşitli hedeflerin yer aldığı görülmektedir.

Okul terki; bir öğrencinin kayitlı olduğu programı tamamlamadan, bir lise diplomasına veya buna eşdeğer bir belgeye sahip olmadan okuldan ayrılması olarak tanımlanmaktadır (NCES, 2020). Avrupa Birliği tarafından ise 18-24 yaşları arasında olup ortaöğretim kademesinden daha düşük öğrenim durumuna sahip öğrencilerin okuldan erken ayrıldığı kabul edilmektedir (EUROSTAT, 2020). Okul terki bireysel, sosyal, ailesel, ekonomik birçok nedenden kaynaklanmaktadır (Gouda ve Sekher, 2014; Marphatia ve diğ., 2019; Weybright, Caldwell, Xie, Wegner ve Smith, 2017). Alanyazın incelendiğinde düşük sosyoekonomik düzey (Nakajima, Kijima ve Otsuka, 2018; Weybright ve diğ., 2017; Wils, Sheehan ve Shi, 2019), ebeveyn eğitim düzeyi (Farah ve Upadhyay, 2017; Mussida, Sciulli ve Signorelli, 2019), hanehalkı nüfusu (Choudhury, 2006; Farah ve Upadhyay, 2017), etnik köken (Cairns, Cairns ve Neckerman, 1989; Ermish ve Francesconi, 2001), devamsızlık (Tabuchi, Fujihara, Shinozaki ve Fukuhara, 2018), sınıf tekrarı (Fisk, 1994), fiziksel veya ruhsal sağlık (Dupere ve diğ., 2018; Mikkonen, Moustgaard, Remes ve Martikainen, 2018; Trampush, Miller, Newcorn ve Halperin, 2009; Vaughn, Salas-Wright ve Maynard, 2014), akran ilişkileri (Robison, Jaggers, Rhodes, Blackmon, ve Church, 2017; Staff ve Kreager, 2008; Stewart, 2007) akademik başarı ve okul dışında bir işte çalışma (Bridgeland, 2010; Montmarquette, Viennot-Briot ve Dagenais, 2007; Tang, Zhao ve Zhao, 2018; Türkiye İstatistik Kurumu-TÜİ, 2020a) gibi değişkenlerin öğrencilerin okulu terk etme riskini etkilediği görülmektedir.

$\mathrm{Bu}$ faktörlere ek olarak alanyazın incelendiğinde okula bağllılı ve okul tükenmişliği değişkenlerinin de eğitimde olumsuz çıtıllara neden olabildiği görülmektedir (Brewster ve Bowen, 2004; Salmela-Aro, Kiuru ve Nurmi, 2008). Finn 
(1989) tarafından okula bağlılık; öğrencilerin kendilerini okulun bir parçası olarak görmeleri, okula karşı aidiyet duygusuna sahip olmaları ve okuldaki gerek akademik gerek sosyal konularda etkin (aktif) olmaları şeklinde tanımlanmaktadır. Ayrıca Fredricks, Blumenfeld ve Paris (2004) okula bağlılı̆̆ın davranışsal (okul etkinliklerine ve ders dışı etkinliklere katılım vb.), duygusal (okula karşı ilgi vb.) ve bilişsel (öğrenmeye güdülenme vb.) olmak üzere üç boyutla kavramlaştırılmasını önermektedir. Alanyazın incelendiğinde okula yabancılaşma, düşük akademik başarı ve okul terki gibi olumsuz akademik çıktıları önlemede okula bağlılığın önemli bir etken olduğu, okula bağlılığın artması sonucu lise öğrencilerinin mezun olma olasılıklarının da arttığı vurgulanmaktadır (Fall ve Roberts, 2012). Ergenlik döneminde duygusal ve davranışsal açıdan okula bağlılıkları düşük olan öğrencilerin akademik performaslarının (edimlerinin) düştüğü (Niehaus, Rudasill ve Rakes, 2012) ve düşük duygusal ve davranışsal bağlılığın okul terkinin anlamlı bir yordayıcısı olduğu alanyazındaki diğer çalışmalarda da vurgulanmaktadır (Im, Hughes ve West, 2016; Magen-Nagar ve Shachar, 2017, Zorbaz ve Özer, 2020). Ayrıca okula bağlılık ve riskli davranışlarda bulunma arasında anlamlı ilişkinin olduğu, öğrencilerin okula bağlılık düzeyleri arttığında antisosyal davranışlarda bulunma, okulu terk etme gibi riskli davranışlarda bulunma olasılıklarının azaldığı görülmektedir (Şimşek ve Çöplü, 2018). Okul tükenmişliği ise öğrencinin okuldaki etkinlikleri sürdürecek gücü kendisinde bulamaması, okulla ilgili etkinliklere ilgisizlik göstermesi, benlik saygısının ve akademik başarı algısının düşmesi şeklinde tanımlanmaktadır (Zhang, Gan ve Cham, 2007). Yapılan önceki araştırmaların sonuçları okul tükenmişliği yaşayan öğrencilerin daha fazla devamsızlık yaptıklarını, okula bağlılıklarının düşük olduğunu, okulla ilgili görevleri yerine getirmekte daha düşük güdülenmeye sahip olduklarını ve okulu bırakma risklerinin daha yüksek olduğunu göstermektedir (Bask ve Salmela-Aro, 2013; Salmela-Aro, Savolainen ve Holopainen, 2009; TuominenSoini ve Salmela-Aro, 2014). Sonuç olarak alanyazındaki tüm bu çalışmalar göz önünde bulundurulduğunda birçok etkenin etkisiyle ortaya çıkan okulu terk etme davranışının karmaşık bir sürecin sonucu olduğu söylenebilir.

Okul terki; bireysel, sosyal, ekonomik birçok soruna neden olabilmektedir. Örneğin, okulu terk eden bireylerin işsizlik veya düşük maaşlı işlerde çalışma (Annabi, 2017; Bjerk, 2012; Campbell, 2015; Doll ve Hess, 2001; Mussida ve diğ., 2019; NCES, 2015; Sweeten, Shawn ve Raymond, 2009), suç işleme (Backman, 2017; Harlow, 2003; Itzhaki, Itzhaky ve Yablon, 2018; Thornberry, Moore ve Christenson, 1985; White ve Kelly, 2010), tütün, alkol veya uyuşturucu madde kullanma (Lansford, Dodge, Pettit ve Bates, 2016; Townsend, Flisher ve King, 2007) ve erken yaşta cinsel deneyim veya hamilelik (Fall ve Roberts, 2012; Suh, Suh ve Houston, 2007; White ve Kelly, 2010) gibi birtakım önemli sorunlar yaşama riski yüksektir. Ayrıca okulu terk eden bireyler ülke ekonomisi için de önemli bir sorundur. Mesela okulu terk ederek vergilerini ödemeyen ve devlet yardımı alan her bireyin Amerika Birleşik Devletleri ekonomisinde 250 bin dolarlık önemli bir kayba neden olduğu tahmin edilmektedir (NCES, 2015). Okul terkinin neden olduğu bu olumsuz sonuçlar göz önüne alındığında bu durumun önlenmesine ve bu durumla ilişkili 
etkenlerin belirlenmesine yönelik yapılacak araştırmaların önemi de anlaşılacaktır. Bu ilişkilerin ortaya konulması önleyici rehberlik ve psikolojik danışma hizmetleri kapsamında okul psikolojik danışmanlarının hazırlayacakları önleme veya müdahale programlarının etkisini artıracaktır. Ayrıca ergenlik döneminin riskli davranışların en fazla görüldüğü dönem olması (Gençtanırım ve Ergene, 2014) göz önünde bulundurularak bu araştırmanın ortaöğretim öğrencileriyle yürütülmesine karar verilmiştir. Riskli davranışlar sigara, alkol ve uyuşturucu madde kullanımından erken cinsel deneyime; antisosyal davranışlardan okul terkine kadar birçok davranışı içermekte ve bireylerin fiziksel veya ruhsal sağlığını olumsuz etkilemektedir (Özdemir, 2018). Ortaöğretim düzeyinin denk geldiği ergenlik dönemi ruhsal bozuklukların ortaya çıkma olasıllı̆ının oldukça yüksek olduğu bir dönemdir. Nitekim tüm yaşam boyu ruhsal bozuklukların yaklaşık \%50'si 13-19 yaşları arasında ortaya çıkmaktadır (Kessler ve diğ., 2007). Ortaöğretim kademesinde okulu terk etme ise bireylerin birtakım ruhsal bozukluklar yaşama olasılığını artırmaktadır (Ramsdal, Bergvik ve Wynn, 2018). O nedenle öğrencilerin okul terki gibi riskli davranışlarda bulunma olasılıklarını azaltmaya yönelik okul psikolojik danışmanları tarafından yapılacak önleme çalışmaları için ortaöğretim düzeyi kritik bir dönemdir. $\mathrm{Bu}$ bağlamda, bu araştırmada ortaöğretim öğrencilerinin okulu terk etme riskleri; okula bağlılık ve okul tükenmişliği değişkenleri açısından incelenmiştir. Ayrıca cinsiyet, hanehalkı nüfusu, sınıf düzeyi, ailenin gelir durumu, şu an bir işte çalışıyor olma, daha önce bir işte çalışmış olma, algılanan okul başarısı, sınıf tekrarı yapma, disiplin cezası almış olma, süreğen hastalık, okuldan kaçma ve devamsızlık değişkenlerinin okul terki riski üzerindeki etkisinin de incelenmesi amaçlanmıştır. Araştırmanın amacı doğrultusunda yanıtları aranan araştırma soruları ise şu şekildedir;

1. Ortaöğretim öğrencilerinin okul terki riski, okula bağl1lık ve okul tükenmişliği puanları arasında anlamlı ilişki var mıdır?

2. Okula bağll1ık ve okul tükenmişliği ortaöğretim öğrencilerinin okulu terk etme riskini anlamlı bir şekilde yordamakta mıdır?

3. Ortaöğretim öğrencilerinin okul terki riski cinsiyete, hanehalkı nüfusuna, sınıf düzeyine, ailenin gelir durumuna, şu an bir işte çalışıyor olma, daha önce bir işte çalışmış olma, algılanan okul başarısı, sınıf tekrarı yapma, disiplin cezası almış olma, süreğen hastalık, okuldan kaçma ve devamsızlık değişkenlerine göre farklılık göstermekte midir?

\section{Yöntem}

Bir araştırmanın yöntem kısmının ayrıntılı biçimde açıklanması araştırmanın tekrarlanabilirliğini ve araştırma sonuçlarının test edilebilirliğini sağlamaktadır (Büyüköztürk, Kılıç-Çakmak, Akgün, Karadeniz ve Demirel, 2008). Bu bilgiler göz önünde bulundurularak bu başlık altında araştırma modeli, araştırmada kullanılan örnekleme yöntemi, örnekleme seçilen öğrencilerin özellikleri, kullanılan veri toplama araçları, işlem, verilerin çözümlenmesinde kullanılan yol, geçerlik ve güvenirlik çalışmaları ayrıntılı olarak açıklanmıştır. 


\section{Araştırma Modeli}

$\mathrm{Bu}$ araştırma nicel bir araştırma olup korelasyonel desene dayanmaktadır. Korelasyonel çalışmalar, herhangi birine müdahale edilmeksizin birbirinden farklı en az iki değişkenin ilişkili değişkenler olup olmadığı ve eğer bu iki değişken arasında herhangi bir ilişki varsa ilişkinin yönünü belirlemek amacıyla yapılmaktadır (Creswell, çev. 2019). Bu araştırmada okula bağlılık, okul tükenmişliği, okul terki riski ve çeşitli demografik değişkenler arasındaki ilişkiler incelenmiştir.

\section{Evren-Örneklem}

Araştırmanın hedef evrenini ortaöğretim öğrencileri oluştururken ulaşılabilir evrenini Giresun il merkezindeki ortaöğretim öğrencileri oluşturmaktadır. Araştırmanın örneklemini ise, 2019-2020 öğretim yılında Giresun il merkezindeki Atatürk Mesleki ve Teknik Anadolu Lisesi, Hamdi Bozbağ Anadolu Lisesi ve Mimar Sinan Anadolu Lisesinde öğrenim gören 237'si (\%56.4) kadın ve 183’ü (\%43.6) erkek olmak üzere toplam 420 ortaöğretim öğrencisi oluşturmaktadır (Tablo 1). Örneklem büyüklüğüne karar verirken GPower 3.1 programı kullanılmıştır. Yapılan çözümlemede .80 güç ve .30 etki büyüklüğü elde edebilmek için örneklem büyüklüğünün yaklaşık 400 olması gerektiği görülmüştür (Şekil 1).

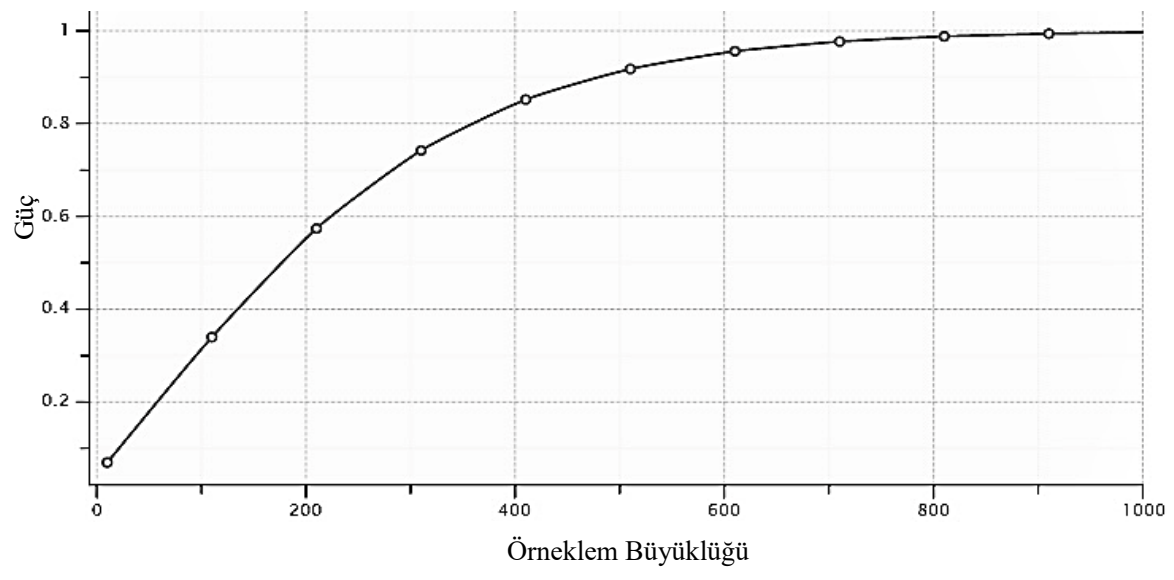

Şekil 1. Örneklem Büyüklüğü ve Güç

Okullar belirlenirken okul terki riski incelendiği için en zengin verilerin elde edilebileceği durumlar göz önünde bulundurulmuștur. Bu doğrultuda başarı düzeyi düşük ve yüksek okullar ve farklı okul türleri belirlenerek bu okullarda öğrenim gören öğrencilerden uygun örnekleme yöntemiyle veriler toplanmıştır. Uygun örnekleme yöntemi, örnekleme seçilen bireylerin çalışmaya uygunluğunun ve istekliliğinin göz önünde bulundurulduğu, örneklem belirlenirken zaman ve kaynaklar bakımından 
ekonomiklik sağlayan bir örnekleme yöntemidir (Büyüköztürk ve diğ., 2008). Tablo 1 'de katılımcıların demografik özellikleri verilmiştir.

Tablo 1

Katılımcıların Demografik Özellikleri $(N=420)$

\begin{tabular}{llrr}
\hline Değişken & Grup & $\boldsymbol{f}$ & $\boldsymbol{\%}$ \\
\hline Cinsiyet & Kadın & 237 & 56.4 \\
& Erkek & 183 & 43.6 \\
\hline Ailenin Gelir Durumu & Kötü & 13 & 3.1 \\
& Orta & 311 & 74 \\
& İyi & 96 & 22.9 \\
\hline Okul Türü & Anadolu & 153 & 36.4 \\
& Mesleki ve Teknik & 267 & 63.6 \\
\hline Sınıf Düzeyi & 9 & 140 & 33.3 \\
& 10 & 121 & 28.9 \\
& 11 & 95 & 22.6 \\
& 12 & 64 & 15.2 \\
\hline Şu An Bir İşte Çalışma Durumu & Evet & 6 & 1.4 \\
& Hayır & 414 & 98.6 \\
\hline Daha Önce Bir İşte Çalışma Durumu & Evet & 68 & 16.2 \\
& Hayır & 352 & 83.8 \\
\hline Okul Başarısı & Kötü & 22 & 5.2 \\
& Orta & 296 & 70.5 \\
& İyi & 102 & 24.3 \\
\hline Sınıf Tekrarı Yapma & Evet & 16 & 3.8 \\
& Hayır & 404 & 96.2 \\
\hline Disiplin Cezası Alma Durumu & Evet & 36 & 8.6 \\
& Hayır & 384 & 91.4 \\
\hline Süreğen Hastalık & Evet & 44 & 10.5 \\
& Hayır & 376 & 89.5 \\
\hline Okuldan Kaçma & Evet & 35 & 8.3 \\
& Hayır & 385 & 91.7 \\
\hline Devamsızlık & 10 Günden Az & 404 & 96.2 \\
& 10 Günden Çok & 16 & 3.8 \\
\hline
\end{tabular}

Örnekleme seçilen öğrencilerin yaşlarının ortalaması 15.4'tür. Tablo 1 incelendiğinde de görülebileceği üzere 420 öğrencinin 153’ü (\%36.4) anadolu lisesine giderken 267'si (\%63.6) mesleki ve teknik anadolu lisesine gitmektedir. Öğrencilerin 140'1 (\%33.3) 9. sinıf, 121'i (\%28.9) 10. sinıf, 95'i (\%22.6) 11. sinif, 64'ü (\%15.2) 12. sınıftır. Ayrıca öğrencilerin 6'sı (\% 1.4) şu anda bir işte çalışıyorken 68 'i (\% 16.2) şu an olmasa bile daha önce bir işte çalışmıştır. Ayrıca sınıf tekrarı yapan öğrencilerin sayısının 16 (\% 3.8), disiplin suçu bulunan öğrencilerin sayısının 36 (\%8.6), süreğen bir rahatsızlığı bulunan öğrenci sayısının 44 (\%10.5), sık sık okuldan kaçan öğrenci sayısının $35(\% 8.3)$ ve on günden fazla devamsızlığı olan öğrenci sayısının $16(\% 3.8)$ olduğu görülmektedir. 


\section{Veri Toplama Araçları}

Ölçekleri geliştiren veya uyarlamasını yapan araştırmacıların onayının alınmasının ardından bu araştırmada Okul Terki Riski Ölçeği, Okul Tükenmşliği Ölçeği, Okula Bağl1lık Ölçeği ve kişisel bilgi formu kullanılmıştır.

Okul terki riski ölçeği. Sütçü (2015) tarafindan geliştirilen ölçek 33 maddeden oluşan beşli derecelendirmeye sahip likert tipi bir ölçektir. Başarısızlık algısı, sessiz davranma ve antisosyal davranma şeklindeki üç alt boyuttan oluşan ölçeğin; başarısızlık alt boyutu için Cronbach Alfa katsayısı .84, sessiz davranma alt boyutu için Cronbach Alfa katsayısı .85 ve antisosyal davranma alt boyutu için Cronbach Alfa katsayıs1 .92 olarak verilmektedir. Sütçü (2015) tarafından ilişkili üç faktör, ilişkisiz üç faktör ve tek faktör olmak üzere ölçüm modelleri test edilmiştir. En iyi genel uyum katsayılarının ilişkili üç faktör modeline ait olduğu görülmüştür. Bu modelin uyum iyiliği değerlerinin; $\chi^{2}=554.3, \mathrm{sd}=492, p=.03, \chi^{2} / \mathrm{sd}=1.13, \mathrm{CFI}=$ .97 şeklinde olduğu görülmektedir. Ancak önerilen modelin bu çalışmanın amacına uygun olmadığı düşünülerek alternatif modeller incelenmiştir. Tek faktörlü alternatif modele ilişkin uyum iyiliği değerlerinin $\chi^{2}=539.1, \mathrm{sd}=495, p=.08, \chi^{2} / \mathrm{sd}=1.08$ ve $\mathrm{CFI}=.82$ şeklinde olduğu görülmektedir. Ki kare değerleri, oluşturulan model ile verinin uyumunu göstermektedir. Veriye uyan bir model geliştirmek için anlamlı olmayan bir ki kare değeri istenir (Tabachnick ve Fidell, 2020). Tek faktörlü alternatif modelin bu durumu sağladığı görülmektedir $(p>.05)$. Ki kare değerinin anlamlılık düzeyi örneklem büyüklüğünden etkilenebildiği için ayrıca ki karenin serbestlik derecesine bölümü de model uyumunu değerlendirmek için kullanılmakta ve bu sonucun 3'ten küçük olması gerekmektedir (Marcoulides ve Schumacher, 2007). Tek faktörlü alternatif modele ait bu değer 1.08'dir. Buna ek olarak tek faktörlü alternatif modele ait CFI değerinin kabul edilebilir değerin altında olduğu görülmektedir. Nitekim .95 'ten büyük CFI değerleri modelin mükemmel uyuma sahip olduğunu gösterirken bu değer düştükçe model uyumunun bozulduğu söylenebilir. Tek faktörlü alternatif modelin CFI değerinin .82 olması araştırma modelinin uyumunun .82 olduğu veya temel modelin uyumundan $\% 82$ daha iyi olduğu anlamına gelmektedir (Kline, çev. 2019). Son olarak Sütçü'nün çalışmasında RMSEA değerleri de verilmiş olmasına karşın bu değerler göz önünde bulundurulmamıştır. Çünkü RMSEA değeri örneklem büyüklüğüne çok duyarlıdır. Örneklem büyüklüğü nedeniyle RMSEA doğru modelleri aşırı reddetmektedir (Tabachnick ve Fidell, 2020). Tüm bunlar göz önünde bulundurularak Sütçü tarafindan test edilen modellerden tek faktörlü alternatif modelin kullanılmasına karar verilmiştir. Tüm istatistiksel modeller bir miktar hata içerir. Ortalamanın en az hata ürettiği göz önünde bulundurularak ölçekte toplam puan alınırken puan ortalamaları kullanılmıştır (Field ve Hole, çev. 2019). Son olarak Sütçü (2015) çalışmasında önerdiği modele ilişkin Cronbach Alfa değerlerini verirken alternatif modellerin Cornbach Alfa değerlerini vermemiştir. Ancak bu araştırmada Okul Terki Riski Ölçeğinin ortaöğretim öğrencileri örneklem grubu için Cronbach Alfa katsayıs1 .92 olarak bulunmuştur. 
Okul tükenmişliği ölçeği. Ölçek, Salmela-Aro, Kiuru, Leskinen ve Nurmi (2009) tarafından öğrencilerin okul tükenmişliği düzeylerini belirlemek için geliştirilmiş olup Türkçe'ye Seçer, Halmatov, Veyis ve Ateş (2013) tarafindan kazandırılmıştır. Dokuz maddeden oluşan beşli derecelendirmeye sahip likert tipi bir ölçek olan okul tükenmişliği ölçeği; Duygusal Tükenmişlik, Duyarsızlaşma ve Düşük Kişisel Başarı Hissi olmak üzere üç alt boyuttan oluşmaktadır. Yapılan açımlayıcı faktör analizi sonucunda açıklanan toplam varyansın $\% 66.8$ olduğu görülürken doğrulayıcı faktör analizi sonucunda ise model uyum iyiliği değerlerinin RMSEA = $.042, \mathrm{RMR}=.013, \mathrm{NFI}=.90, \mathrm{CFI}=.96, \mathrm{IFI}=.97, \mathrm{RFI}=.92, \mathrm{AGFI}=.90, \mathrm{GFI}=.92$ şeklinde olduğu görülmektedir. Ölçeğin geneline ait Cronbach Alfa katsayısı .75 ve test tekrar test güvenirlik katsayısı .80 olarak verilmiştir. Bu araştırmada Okul Tükenmişliği Ölçeğinin ortaöğretim öğrencileri örneklem grubu için Cronbach Alfa katsayısı .84 olarak bulunmuştur.

Okula bağlılık ölçeği. Türkçe’ye uyarlaması Çengel, Totan ve Çöğmen (2017) tarafından yapılan okula bağlılık ölçeğinin aslı Fredricks, Blumenfeld, Friedel ve Paris (2005) tarafından geliştirilmiştir. Ölçek 19 maddelik beşli derecelendirmeli likert tipi bir ölçektir. Ölçekte üç madde ters puanlanırken alınabilecek en düşük puan 19, en yüksek puan 95'dir. Ölçeğin; Ddavranışsal, Duyuşsal ve Bilişsel olmak üzere üç alt boyuttu vardır. Yapılan doğrulayıcı faktör analizi sonucunda model uyum iyiliği değerlerinin $\chi^{2}=618.90, \mathrm{sd}=49, \chi^{2} / \mathrm{sd}=4.15, \mathrm{CFI}=.96, \mathrm{SRMR}=.05$ şeklinde olduğu görülmektedir. Ölçeğin geneline ait test tekrar test güvenirlik katsayısı .83'tür. Ölçeğin davranışsal alt boyutu için Cronbach Alfa katsayısı .68, duyuşsal alt boyutu için Cronbach Alfa katsayısı .80 ve bilişsel alt boyutu için Cronbach Alfa katsayısı .80 olarak verilmiştir. McDonald's Omega değerleri ise davranışsal alt boyur için .74, duyuşsal alt boyut için .83 ve bilişsel alt boyut için .85'tir. Çengel ve diğ. (2017) ölçeğin geneline ait Cronbach Alfa katsayısını .89 olarak verirken; bu araştırmada Okul Bağlılık Ölçeğinin ortaöğretim öğrencileri örneklem grubu için Cronbach Alfa katsayısı .81 olarak bulunmuştur.

Kişisel bilgi formu. Cinsiyet, yaş, okul başarısı, ailenin ekonomik durumu, okul devamsızlığı, sınıf tekrarı yapma, daha önce bir işte çalışma, şu anda bir işte çalışma, süreğen hastalık, ders başarısı, okuldan kaçma gibi bir takım değişkenlere ait bilgileri elde etmek amacıyla araştırmacı tarafından hazırlanmıştır. Tabuchi ve diğ. (2018) tarafından yapılan çalışmada 10 günden fazla devamsızlığı olan öğrencilerin okulu terk etme risklerinin daha yüksek olduğu yönündeki bulgu göz önünde bulundurularak devamsızlık yapılan gün sayısı için 10 günden az ve 10 günden fazla olmak üzere iki sınıflandırma yapılmıştır. Okuldan kaçma değişkeni için böyle bir gruplandırma yapılmaksızın öğrencilerin algısına göre cevaplar alınmıştır.

\section{İşlem}

Araştırma için veri toplanmadan önce Giresun İl Milli Eğitim Müdürlüğüne araştırma izni için başvuru yapılmış ve araştırmanın yapılması Giresun İl Milli Eğitim Müdürlüğünün 04.11.2019 tarih ve 21702701 sayılı kararı ile uygun bulunmuştur. Bu izin alındıktan sonra Atatürk Mesleki ve Teknik Anadolu Lisesi, Hamdi Bozbağ 
Anadolu Lisesi ve Mimar Sinan Anadolu Lisesinden 05.12.2019 ile 20.12.2019 tarihleri arasında veriler toplanmıştır. Veri toplanan okullar belirlenirken okul terki riski incelendiği için en zengin verilerin elde edilebileceği durumlar göz önünde bulundurulmuştur. Bu doğrultuda başarı düzeyi düşük ve yüksek okullar belirlenerek bu okullardan uygun örnekleme yöntemiyle veriler toplanmıștır. Her öğrenciye ölçek formlarıyla birlikte araştırmayla ilgili bilgilendirilmiş onam formu verilmiştir. Bilgilendirilmiş onam formunda; araştırmanın amacı, araştırmaya katılacak öğrencilerin hakları, araştırmacı ile ilgili bilgilere yer verilmiştir. Öğrencilere ölçek formlarını doldurmaları için bir hafta süre verilmiștir. Bu süre içerisinde ölçekleri gönüllü olarak dolduran öğrencilerin ölçek formlarını ölçek maddeleri görünmeyecek şekilde katlayıp araştırmacı tarafından kendilerine verilen zarfların içine koyarak okul yönetimine bırakılan klasörün içerisine atmaları istenmiştir. Buna ek olarak öğrenci bilgilerinin gizliliği için ölçek formalarına veya zarfların üzerine ad, soyad yazmamaları da istenmiştir. Ayrıca bu süre içinde ölçek formu veya araştırmayla ilgili ek bilgiye gerek duyan öğrencilerin bilgilendirilmiş onam formunda verilen iletişim kanallarını kullanarak araştırmacıyla iletişim kurabilecekleri de vurgulanmıştır. Bir haftanın sonunda araştırmacı ölçek formlarını okul yönetiminden teslim almıştır.

\section{Verilerin Analizi}

Toplanan veriler SPSS paket programına aktarılmıștır. Veri setinin çözümlenmesinde kullanılacak testlere karar vermek için öncelikle eksik veya hatalı verilerin olup olmadığı ve veri setinin normal dağılıp dağılmadığı kontrol edilmiştir. Veri setinde kayıp verilerin rastgele mi yoksa sistematik bir şekilde mi dağıldığına bakılmış ve kayıp veriler yerine veri setinin ortalaması atanmıştır. Veri setinin normallik varsayımlarını sağlayıp sağlamadığını incelemek için frekans tabloları, Çarpıklık-Basıklık değerleri, histogram grafiği, Q-Q plot ve P-P plot grafikleri incelenmiş̧ir (Tablo 2).

Tablo 2

Çarpıklık (Skewness) ve Basıklık (Kurtosis) Değerleri

\begin{tabular}{lrrrrrr}
\hline & \multicolumn{2}{c}{ Çarpıklık (Skewness) } & & \multicolumn{2}{c}{ Basıklı (Kurtosis) } \\
\cline { 2 - 3 } \cline { 5 - 6 } & İstatistik & \multicolumn{2}{c}{ Standart Hata } & & Istatistik & Standart Hata \\
\hline Okula Bağll1ık & -.37 & .11 & & .31 & .23 \\
Okul Tükenmişliği & .23 & .11 & & -.12 & .23 \\
Okul Terki Riski & 1 & .11 & & 1.6 & .23 \\
\hline
\end{tabular}

Tablo 2'de verilen çarpıklık ve basıklık değerleri incelendiğinde -1.5 ve +1.5 arasında dağılım gösterdiği görülmektedir. Bu sonuçlar Tabachnick ve Fidell'e (2020) göre verilerin normal dağılıma sahip olduğunu göstermektedir. Bu doğrultuda veri seti analiz edilirken parametrik testlerden t-testi, Pearson Korelasyon Analizi, Çoklu Doğrusal Regresyon Analizi kullanılmıştır. Bu testlerin uygulanması için varyansların eşit dağılımı, normal dağılım, çoklu doğrusallık, uç değerler gibi gerekli olan ön koşullara da dikkat edilmiş, Levene's, Mahalanobis, VIF ve tolerans değerleri 
incelenmiştir. Disiplin cezası alma, hanehalkı nüfusu, okul başarısı, sınıf düzeyi, sınıf tekrarı yapma, devamsızlık yapılan gün sayısı, şu anda bir işte çalışma, ailenin gelir durumu ve okul başarısı değişkenlerine ilişkin Levene's analizinde varyansların eşit dağılmadığı görülmüştür ve bu değişkenler analizlerden çıkarılmıştır. Verilerin uç değerler içerip içermediğine $\mathrm{z}$ puanlarına ve Mahalanobis uzaklık değerlerine bakılarak karar verilmiştir. Buna göre $\mathrm{z}$ puanlarının \pm 3 aralı̆ı̆ında olması ve Mahalanobis uzaklık değerlerinin üç yordayan değişken için ölçüt kabul edilen 16.27 değerinin altında olması nedeniyle veri setindeki değerlerin analizi olumsuz etkilemeyeceği kabul edilmiştir (Seçer, 2013). Daha sonra artıkların doğrusallığı ve eşdeğişkenliğine bakılmış ve çözümleme sonucu elde edilen histogram, scatterplot, normal P-P plot ve kısmi regresyon grafikleri incelendiğinde çoklu doğrusal regresyon analizi için bu sayıltının da karşılandığına karar verilmiştir. Tabachnick ve Fidell (2020) çoklu doğrusallık sayıltısını test etmek için analize dahil edilen değişkenler arasında korelasyon katsayısının hesaplanmasını önermekte ve değişkenler arasındaki korelasyon katsayısının .90 'nın altında bir değere sahip olması gerektiğini belirtmektedir. $\mathrm{Bu}$ doğrultuda yapılan çözümlemede değişkenler arasındaki korelasyon katsayısının .90 ve üzeri olmadığı görülmüştür. Son olarak VIF değeri ve tolerans değerleri de incelenmiş ve VIF değerinin 1.23 ve tolerans değerinin .81 olduğu görülmüştür. VIF ve tolerans değerlerinin de çoklu doğrusal regresyon analizinin sayıltılarını karşıladığına karar verilmiştir.

$t$ istatistiğinin istatistiksel olarak önemli olması uygulamada da önemli bir etkiye sahip olduğu anlamına gelmez (Field ve Hole, çev. 2019). Bu doğrultuda yapılan Bağımsız Örneklemler İçin t Testi analizinde anlamlı fark bulunan değişkenler için etki büyüklüğü hesaplanmıştır. Etki büyüklü hesaplanırken $t$ istatistiği $r$ değerine dönüştürülmüştür. Bu dönüşümü yapmak için $r=\sqrt{t^{2} / t^{2}+s d}$ formülü kullanılmıştır (Field ve Hole, çev. 2019). Bu formülde bağımsız örneklemler için t testi analizinde elde edilen $t$ değerinin karesi alınıp, $t$ değerinin karesi ile serbestlik derecesinin toplamına bölünmüştür ve elde edilen sayının karekökü alınmıştır. Elde edilen $r$ değeri etki büyüklüğünü göstermektedir. Cohen (1992) tarafindan .10 ile .30 arasındaki $r$ değerlerinin küçük etki, .30 ile .50 arasındaki değerlerin orta etki ve .50 ve üzerindeki $r$ değerlerinin büyük etkiyi gösterdiği ifade edilmektedir. Elde edilen $r$ değerleri bu aralıklar göz önünde bulundurularak değerlendirilmiş̧ir.

\section{Bulgular}

$\mathrm{Bu}$ araştırmada ortaöğretim öğrencilerinin okulu terk etme riskleri; okula bağlılık ve okul tükenmişliği değişkenleri açısından incelenmektedir. Ayrıca cinsiyet, ailenin ekonomik durumu, hanehalkı nüfusu, algılanan okul başarısı gibi birtakım değişkenlerin okul terki riski üzerindeki etkisinin de incelenmesi amaçlanmıştır. $\mathrm{Bu}$ doğrultuda yapılan analizler ve bu analizlerin sonuçları sırasıyla verilmiştir.

Araştırma sorularından ilki ortaöğretim öğrencilerinin okul terki riski, okul tükenmişliği ve okula bağlılık puanları arasında anlamlı bir ilişkinin olup olmadığını belirlemeye yöneliktir. Bu araştırma sorusuna yönelik yapılan Pearson Korelasyon Analzi sonuçları Tablo 3'te gösterilmektedir. 
Ortaögretim Ögrrencilerinde Okul Terki Riskinin Yordayıcılarl: Okula Bağlllık ve Okul Tükenmisliğgi 441

Tablo 3

Okula Bağlılık, Okul Tükenmişliği ve Okul Terki Riski Korelasyon Analizi Sonucu

\begin{tabular}{lrrr}
\hline & Okula Bağlılık & Okul Tükenmişliği & Okul Terki Riski \\
\hline Okula Bağlllık & - & & \\
Okul Tükenmişliği & $-.43^{*}$ & - & \\
Okul Terki Riski & $-.47^{*}$ & $.52^{*}$ & \\
\hline$* p<.05$ & & &
\end{tabular}

Ortaöğretim öğrencilerinin okul terki riski ile okula bağlılık ve okul tükenmişliği puanları arasındaki ilişkiyi ve ilişkinin yönünü belirlemek için yapılan Pearson korelasyon analizi sonucunda okul terki riski ile okula bağlılık arasında negatif yönde anlamlı bir ilişki $(r=-.47, p<.05)$ ve okul terki riski ile okul tükenmişliği arasında ise pozitif yönde anlamlı bir ilişki olduğu $(r=.52, p<.05)$ bulunmuştur (Tablo 3). Bu bağlamda ortaöğretim öğrencilerinin okula bağlılık puanlarının artması durumunda okul terki riski puanlarının azalacağı; okul tükenmişliği puanlarının artması durumunda ise okul terki riskinin de artacağı söylenebilir. Araştırmada ayrıca okula bağlılık ve okul tükenmişliği değişkenlerinin ortaöğretim öğrencilerinin okul terki riskini anlamlı biçimde yordayıp yordamadığının belirlenmesi de amaçlanmıştır. Bu amaç doğrultusunda yapılan Çoklu Doğrusal Regresyon Analizi sonuçları Tablo 4'te gösterilmektedir.

Tablo 4

Okul Teri Riski Çoklu Doğrusal Regresyon Analizi Sonucu

\begin{tabular}{lrrrrr}
\hline Değişken & $\boldsymbol{B}$ & Standart Hata & $\boldsymbol{\beta}$ & $\boldsymbol{t}$ & $\boldsymbol{p}$ \\
\hline Sabit & 2.45 & .23 & & 10.2 & .00 \\
Okula Bağll1ık &. .36 & .05 & -.30 & -7 & .00 \\
Okul Tükenmişliği & .31 & .03 & .39 & 9 & .00 \\
\hline
\end{tabular}

Çoklu doğrusal regresyon analizi sonucunda okula bağlılık ve okul tükenmişliği ile okul terki riski arasında anlamlı ilişki olduğu bulunmuştur $\left(R=.59,{ }^{2}=.35, p<\right.$ $.01)$. Buna göre okula bağlılık ve okul tükenmişliği, okul terki riskindeki toplam varyansın \%35'ini açıklarken Standardize edilmiş $(\beta)$ katsayısı ve $t$ değeri incelendiğinde ise sırasıyla okul tükenmişliğinin ve okula bağlılığın okul terki riskinin anlamlı bir yordayıcısı olduğu görülmektedir. Ayrıca Tablo 4 incelendiğinde görülebileceği üzere okula bağlılık değişkeninde meydana gelecek bir birimlik artış ortaöğretim öğrencilerinin okul terki riskinde .36'lik birim düşüşe neden olurken; okul tükenmişliği değişkeninde meydana gelecek bir birimlik artış ise ortaöğretim öğrencilerinin okul terki riskinde .31 'lik bir artışa neden olmaktadır.

Tablo 5'te ise cinsiyet, daha önce bir işte çalışma, süreğen hastalık, okuldan kaçma ve okul türü değişkenlerine göre ortaöğretim öğrencilerinin okulu terk etme riski puan ortalamasının anlamlı olarak farklılaşıp farklılaşmadığını test etmek için yapılan Bağımsız Örneklemler İçin t-Testi analizinin sonuçları görülmektedir. 
Tablo 5

Okul Terki Riskine İlişkin T-Testi Sonuçları

\begin{tabular}{llrrrrr}
\hline & Cinsiyet & $\boldsymbol{N}$ & $\boldsymbol{x}$ & $\boldsymbol{S . s}$ & $\boldsymbol{t}$ & $\boldsymbol{p}$ \\
\hline Cinsiyet & Kadın & 237 & 2 & .69 & \multirow{2}{*}{4.58} & \multirow{2}{*}{.000} \\
& Erkek & 183 & 2.4 & .76 & & \\
\hline \multirow{2}{*}{ Daha Önce Bir İşte Çalışma Durumu } & Evet & 68 & 2.4 & .81 & \multirow{2}{*}{3.43} & \multirow{2}{*}{0.01} \\
& Hayır & 352 & 2.1 & .71 & & \\
\hline \multirow{2}{*}{ Süreğen Hastalık } & Evet & 44 & 2.1 & .54 & \multirow{2}{*}{.39} & \multirow{2}{*}{.697} \\
& Hayır & 376 & 2.2 & .75 & & \\
\hline Okuldan Kaçma & Evet & 35 & 3 & .89 & \multirow{2}{*}{6.93} & \multirow{2}{*}{.000} \\
& Hayır & 385 & 2.1 & .68 & & \\
\hline Okul Türü & Anadolu & 153 & 2.1 & .68 & \multirow{2}{*}{-1.84} & \multirow{2}{*}{.067} \\
& Meslek & 267 & 2.2 & .75 & & \\
\hline
\end{tabular}

Kadın ve erkek ortaöğretim öğrencilerinin okulu terk etme riski puan ortalamalarını karşılaştırmak ve puan ortalamalarının anlamlı olarak bir birinden farklı olup olmadığını belirlemek için yapılan analizin çıktıları incelendiğinde aradaki farkın anlamlı olduğu görülmektedir $\left(t_{418}=4.58, p<.05\right)$. Bu sonuçlara göre erkek öğrencilerin okulu terk etme riskinin $(x=2.4)$, kadın öğrencilerin okulu terk etme riskinden $(x=2)$ daha yüksek olduğu söylenebilir. Etki büyüklüğü hesaplandığında ise $r$ değeri .21 olarak bulunmuş ve bu da küçük düzeyde bir etki büyüklüğünün olduğunu göstermektedir. Daha önce bir işte çalışan ve daha önce bir işte çalışmayan ortaöğretim öğrencilerinin okulu terk etme riski puan ortalamaları arasında herhangi bir anlamlı farklılık olup olmadığını saptayabilmek için yapılan analiz sonucunda puan ortalamalarının anlamlı olarak birbirinden farklılaştığ $3.43, p<.05)$. Daha önce bir işte çalışan ortaöğretim öğrencilerinin okulu terk etme riskinin $(x=2.4)$, daha önce bir işte çalışmayan ortaöğretim öğrencilerinin okulu terk etme riskinden $(x=2.1)$ daha yüksek olduğu söylenebilir. Etki büyüklüğü hesaplandığında ise $r$ değeri .16 olarak bulunmuş ve bu da küçük düzeyde bir etki büyüklüğünün olduğunu göstermektedir. Süreğen bir hastalığı olan ve süreğen bir hastalığ 1 olmayan ortaöğretim öğrencilerinin okulu terk etme riskleri arasında herhangi bir farkın olup olmadığını belirlemek için yapılan analiz sonucunda aradaki farkın anlamsız olduğu görülmektedir $\left(t_{418}=-.39, p>.05\right)$. S1k sik okuldan kaçan ve okuldan kaçmayan ortaöğretim öğrencilerinin okulu terk etme riski puan ortalamaları arasında herhangi bir anlamlı farklılık olup olmadığını saptamak için yapılan analiz sonucunda puan ortalamalarının anlamlı olarak birbirinden farklılaştığı bulunmuştur $\left(t_{418}=6.93, p<.05\right)$. Bu sonuca göre okuldan s1k s1k kaçan ortaöğretim öğrencilerinin okulu terk etme riskinin $(x=3)$, okuldan kaçmayan ortaöğretim öğrencilerinin okulu terk etme riskinden $(x=2.1)$ daha yüksek olduğu söylenebilir. Etki büyüklüğü hesaplandığında ise $r$ değeri .32 olarak bulunmuş ve bu da orta düzeyde bir etki büyüklüğünün olduğunu göstermektedir. Ortaöğretim öğrencilerinin okulu terk etme riski puan ortalamalarının okul türü değişkeni açısından puan ortalamalarının anlamlı bir şekilde birbirinden farklı olup olmadığını belirlemek için yapılan analiz sonucunda aradaki farkın anlamlı olmadığ görülmektedir $\left(t_{418}=-1.84, p>.05\right)$. 


\section{Tartışma, Sonuç ve Öneriler}

$\mathrm{Bu}$ araştırmada ortaöğretim öğrencilerinin okulu terk etme riskleri; okula bağlılık ve okul tükenmişliği değişkenleri açısından incelenmiştir. Ayrıca cinsiyet, hanehalkı nüfusu, sınıf düzeyi, ailenin gelir durumu, şu an bir işte çalışıyor olma, daha önce bir işte çalışmış olma, algılanan okul başarısı, sınıf tekrarı yapma, disiplin cezası almış olma, süreğen hastalık, okuldan kaçma ve devamsızlık değişkenlerinin okul terki riski üzerindeki etkisinin de incelenmesi amaçlanmıştır. Ulaşılan sonuçlar bu bölümde ilgili alanyazın ışığında tartışılmıştır.

Araştırma bulguları ortaöğretim öğrencilerinin okul terki riskinin, okula bağlılıkla negatif yönde; okul tükenmişliğiyle pozitif yönde anlamlı bir ilişki içerisinde olduğunu göstermektedir ve okula bağl1lık ve okul tükenmişliğinin okul terki riskindeki toplam varyansın \%35'ini açıkladığı görülmektedir. Ulaşılan bu sonuçların alanyazındaki diğer araştırmaların sonuçlarını destekler nitelikte olduğu söylenebilir. Nitekim daha önce de vurgulandığı gibi okula yabancılaşma, düşük akademik başarı ve okul terki gibi olumsuz akademik çıktıları önlemede okula bağlılığın önemli bir etken olduğu, okula bağlılığın artması sonucu lise öğrencilerinin mezun olma olasılıklarının arttı̆̆1 görülmektedir (Fall ve Roberts, 2012). Ergenlik döneminde duygusal ve davranışsal açıdan okula bağlılıkları düşük olan öğrencilerin akademik performaslarının (edimlerinin) düştüğü (Niehaus ve diğ., 2012) ve düşük duygusal ve davranışsal bağlılığın okul terkinin anlamlı bir yordayıcısı olduğu yapılan diğer çalışmalarda da vurgulanmaktadır (Im ve diğ., 2016; Magen-Nagar ve Shachar, 2017, Zorbaz ve Özer, 2020). Okul tükenmişliği yaşayan öğrencilerin ise daha fazla devamsızlık yaptıkları, okula bağlılıklarının düşük olduğu, okulla ilgili görevleri yerine getirmekte daha düşük güdülenmeye sahip olduğu görülmektedir (Bask ve Salmela-Aro, 2013; Salmela-Aro, Savolainen ve diğ., 2009; Tuominen-Soini ve Salmela-Aro, 2014). Okula bağlılık ve okul tükenmişliği ile ilgili elde edilen tüm bu bulguların okul terki riskinin çok boyutlu yapısını ortaya koyması, okul terki davranışının daha iyi anlaşılması ve önlenebilmesi için önemli olduğu düşünülmektedir. Bu araştırmada elde edilen bulgular önleyici rehberlik ve psikolojik danışma anlayışı ile okul psikolojik danışmanlarının okula bağlılıkları düşük ve okul tükenmişlikleri yüksek öğrencileri saptayıp bu öğrencilere yönelik müdahale programları hazırlamalarının okul terkinin önlenmesini noktasında oldukça işlevsel olabileceğini bir kez daha göstermektedir.

Cinsiyetin okul terkine etkisi üzerine yapılan araştırmalarda birbirinden farklı sonuçların elde edildiği görülmektedir. Bazı araştırmacılar kadınların (Croninger ve Lee, 2001; Mussida, ve diğ., 2019; Nakajima, ve diğ., 2018) bazı araştırmacılar ise erkeklerin okulu terk etme risklerinin daha fazla olduğunu belirtmektedir (Borgna ve Struffolino, 2017; EUROSTAT, 2020; Laird, DeBell ve Chapman, 2006; Yorğun, 2014). Bazı araştırmalarda ise cinsiyetin okul terkinin anlamlı bir yordayısı olmadığı görülmektedir (Özer, Gençtanırım ve Ergene, 2011; Zorbaz ve Özer, 2020). Okul terki riskinin cinsiyete göre incelendiği araştırmalarda farklı sonuçların ortaya çıkması örneklem grubunun özelliklerinden kaynaklanıyor olabilir. Örneğin, Giresun ilinde 
k1z öğrencilerin ortaöğretim düzeyindeki okullaşma oranları incelendiğinde 2019 yılında \%93 dolayında olduğu görülmektedir. Buna karşın bu oran Rize'de \%98, Muş’ta \%53 civarındadır (TÜİK, 2020b). Milli Eğitim Bakanlığı (2018) verileri incelendiğinde ise Giresun'da genel ortaöğretimde erkek öğrencilerin okullaşma oranlarının kız öğrencilerden daha düşük olduğu görülmektedir. Bu veriler de bölgesel farklılıkların okul terki riski ve okullaşma oranları üzerinde etkili olabileceğini göstermektedir.

Araştırmada elde edilen sonuçlardan biri de daha önce bir işte çalıșan öğrencilerin okulu terk etme risklerinin çalışmayan öğrencilere göre daha yüksek olduğudur. Ulaşılan sonuçlar alanyazınla benzerlik göstermektedir. Nitekim okul dışında bir işte çalışma, daha önce bir işte çalışmış olma ve çocuk işçiliğinin okul terki riskini artırdığı görülmektedir (Bridgeland, 2010, Montmarquette, ve diğ., 2007; Tang ve diğ., 2018). TÜİK (2020a) tarafından paylaşılan verilerde çocuk işgücünün yaklaşık \%80'nini 15-17 yaşları arasındaki ortaöğretim öğrencileri oluşturmaktadır. Herhangi bir işte çalışan çocukların \%35'inin ise okula devam etmediği görülmektedir. Tüm bu araştırmalar okul terki riski için çocuk işçiliğinin önemli bir etken olduğunu ve çocuk işçiliğinin önlenmesine yönelik alınacak önlemlerin okul terki riskini önlemede önemli bir işleve sahip olabileceğini göstermektedir.

Okuldan sık sık kaçan öğrencilerin öğrenimlerini yarıda bırakma risklerinin daha yüksek olduğu sonucuna ulaşılmıştır. Okuldan sık sık kaçma, devamsızlık yapılan gün sayısının artmasına neden olmaktadır. Alanyazın incelendiğinde de okuldan kaçma ve devamsızlık değişkenlerinin okul terkini etkileyen önemli etkenler olduğu görülmektedir (Balfanz, Herzog ve Iver, 2007; Enguita, Martinez ve Gomez, 2010; Finn, 1989; Fortin, Marcotte, Diallo, Potvin ve Royer, 2013; Orfield, 2004).

$\mathrm{Bu}$ araştırmada ayrıca okul türünün okul terki riskini etkileyip etkilemediği incelenmiş ve anlamlı bir farklılık bulunamamıştır. Nitekim okul terkinin mesleki ve teknik ortaöğretim kurumlarında yaygın bir sorun olduğu görülmektedir (Andersen ve diğ., 2018; Tanggaard, 2013). Bu çalışmada okul terki riskinin okul türüne göre farkl1lık göstermemesi beklenmedik bir sonuçtur. Ancak elde edilen sonuç bu çalışmada veri toplanan okulların özelliklerinden kaynaklanıyor olabilir. Veriler Giresun merkezde bulunan Atatürk Mesleki ve Teknik Anadolu Lisesi, Hamdi Bozbağ Anadolu Lisesi ve Mimar Sinan Anadolu Lisesinden toplanmıştır. Bundan sonra yapılacak çalışmalarda veri toplanan okulların tür ve nitelik bakımından çeşitlendirilmesi yapılacak karlılaştırmalarda farklılıkların bulunmasını sağlayabilir. Son olarak araştırmada süreğen hastalığın okul terki riskini etkileyip etkilemediği incelenmiştir. Alanyazın incelendiğinde hem astım, diyabet, hepatit, kanser gibi fiziksel hastalıkların (Mikkonen ve diğ., 2018; Vaughn ve diğ., 2014) hem de depresyon, dikkat eksikliği ve hiperaktivite bozukluğu gibi ruhsal bozuklukların (Dupere ve diğ., 2018; Trampush ve diğ., 2009) okul terki riskini artırdı̆̆ görülmektedir. Ancak bu araştırmada süreğen hastalığa sahip olan ve olmayan ögrencilerin okul terki riskleri arasında anlamlı bir fark bulunamamıştır. Çalışmada süreğen hastalık türü, süresi, önem düzeyi, bireyin tedavi görüp görmediği, ilaç 
kullanımının olup olmadığı gibi süreğen hastalıkla ilgili bilgiler çalışmanın kapsamına dahil edilmediği için bu sonuç ortaya çıkmış olabilir. Nitekim Vaughn ve diğ. (2014) tarafından yapılan çalışmada süreğen hastalık şeklinde genel bir değişken yerine astım, ülser, diyabet, hepatit şeklinde hastalıkların daha somut duruma getirilerek karşılaştırıldığı görülmektedir.

\section{Sınırlılıklar ve Öneriler}

Bu araştırmanın sınırlılıkları, araştırmaya yönelik bir özeleştiri olmanın yanı sıra yapılacak sonraki çalışmalar için de bir öneri niteliği taşımaktadır. Bu doğrultuda çalışmanın sınırlılıklarından ilki okula bağlılık, okul tükenmişliği ve okul terki riski arasındaki ilişkinin çoklu doğrusal regresyon analizi ile incelenmiş olmasıdır. Okul terki riski, okula bağlılık, okul tükenmişliği ve bazı demografik değişkenlerden oluşan bir model kurularak yapısal eşitlik modellemesi ile bu değişkenler arasındaki doğrudan, dolaylı ve aracı etkilerin test edilmesinin alanyazına önemli bir katkı getireceği düşünülmektedir. Bunun dışında yapılacak sonraki çalışmalarda bu araştırmanın bulguları da göz önünde bulundurularak okul terki riskini önlemeye yönelik hazırlanan önleme veya müdahale programlarının deneysel çalışmalarla test edilmesi okul terkiyle ilgili alanyazına önemli bir katkı getirecektir. Nitekim alanyazın incelendiğinde okul terki ile ilgili betimsel çalışmaların sıklıkla yapılmasına karşın deneysel çalışmaların sayısının yetersiz olduğu görülmektedir. Araştırmanın bir diğer sınırlılığı ise uygun örnekleme yönteminin kullanılmış olmasıdır. Yapılacak sonraki çalışmalarda tabakalı örnekleme yönteminin kullanılması bu çalışmada ortaya çıkan gruplar arasındaki dengesiz dağılımları ve varyansların eşit dağılmamasını önleyecektir. $\mathrm{Bu}$ araştırmanın sınırlılıklarından biri de örneklem grubuna seçilen bireylerin yalnızca Giresun ilinden seçilmesidir. Daha önce sözedildiği gibi okullaşma oranlarında iller arasında önemli farklılıklar bulunmaktadır. Bu çalışmanın farklı il veya bölgelerde yapılmasının bu çalışmanın bulgularına ve Türkiye'deki okul terkiyle ilgili alanyazına önemli bir katkı getireceği düşünülmektedir. Son olarak çalışmanın amacına daha uygun olduğu düşünülerek Okul Terki Riski Ölçeği için test edilen modellerden tek faktörlü alternatif modelinin çalışmada kullanılması çalışmanın sınırlılıklarından bir diğeridir. Bu doğrultuda bu ölçeğe ait tek faktörlü alternatif model kullanılırken araştırmacılar tarafından model uyum indekslerinin göz önünde bulundurulması ve geçerlik kanıtlarının yeniden test edilmesi önerilmektedir.

\section{Etik Kurul Kararı}

$\mathrm{Bu}$ araştırma, 01.01.2020 tarihinden önce yapıldığı için etik kurul kararı zorunluluğu taşımamaktadır.

\section{Kaynakça}

Andersen, S., Rod, M. H., Holmberg, T., Ingholt, L., Ersbøll, A. K., and Tolstrup, J. S. (2018). Effectiveness of the settings-based intervention Shaping the Social on preventing dropout from vocational education: A Danish non-randomized controlled trial. BMC Psychology, 6(1), 1-11. doi: 10.1186/s40359-018-0258-8 
Annabi, N. (2017). Investments in education: What are the productivity gains? Journal of Policy Modeling, 39(3), 499-518. doi: 10.1016/j.jpolmod.2017.03.003

Avrupa Komisyonu. (2020). Türkiye 2020 raporu (SWD2020-355). https://www.ab.gov.tr/ilerleme-raporlari_46224.html adresinden erişilmiştir.

Backman, O. (2017). High school dropout, resource attainment, and criminal convictions. Journal of Research in Crime and Delinquency, 54(5) 715-749. doi: $10.1177 / 0022427817697441$

Balfanz, R., Herzog, L., and Iver, D. (2007). Preventing student disengagement and keeping students on the graduation path in urban middle-grades schools: Early identification and effective interventions. Educational Psychologist, 42(4), 223 235. doi: 10.1080/00461520701621079

Bask, M., and Salmela-Aro, K. (2013). Burned out to drop out: Exploring the relationship between school burnout and school dropout. European Journal of Psychology of Education, 28(2), 511-528. doi: 10.1007/s10212-012-0126-5

Bjerk, D. (2012). Re-examining the impact of dropping out on criminal labor outcomes in early childhood. Economics of Education Review, 31(1), 110-122. doi: 10.1016/j.econedurev.2011.09.003

Borgna, C., and Struffolino, E. (2017). Pushed or pulled? Girls and boys facing early school leaving risk in Italy. Social Science Research, 61, 298-313. doi: 10.1016/j.ssresearch.2016.06.021

Brewster, A. B., and Bowen, G. L. (2004). Teacher support and the school engagement of Latino middle and high school students at risk of school failure. Child and Adolescent Social Work Journal, 21(1), 47-67. doi: 10.1023/B:CASW.0000012348.83939.6b

Bridgeland, J. M. (2010). The new dropout challenge: Bridging gaps among students, parents, and teachers. New Directions for Youth Development, 127, 101-110. doi: 10.1002/yd.366

Büyüköztürk, Ş., Kılıç-Çakmak, E., Akgün, Ö. E., Karadeniz, Ş. ve Demirel, F. (2008). Bilimsel araştırma yöntemleri (4. Basım). Ankara: Pegem.

Cairns, R. B., Cairns, B. D., and Neckerman, H. J. (1989). Early school dropout: configurations and determinants. Child Development, 60(6), 1437-1452. doi: $10.2307 / 1130933$

Campbell, C. (2015). The socioeconomic consequences of dropping out of high school: Evidence from an analysis of siblings. Social Science Research, 51(1), 108-118. doi: 10.1016/j.ssresearch.2014.12.011

Choudhury, A. (2006). Revisiting dropouts: Old issues, fresh perspectives. Economic and Political Weekly, 41(51), 5257-5263.

Cohen, J. (1992). A power primer. Psychological Bulletin, 112(1), 155-159. doi: 10.1037/0033-2909.112.1.155 
Creswell, J. W. (2019). Eğitim araştırmalart: Nicel ve nitel araștırmanın planlanmasl, yürütülmesi ve değerlendirilmesi [Educational research: Planning, conducting, and evaluating quantitative and qualitative research] (2. Baskı). (H. Ekşi, Çev.). İstanbul: Edam. (2012)

Croninger, R. G., and Lee, V. E. (2001). Social capital and dropping out of high school: Benefits to at-risk students of teachers' support and guidance. Teachers College Record, 103(4), 548-581. Retrieved from https://psycnet.apa.org/record/2001-05084-002

Çengel, M., Totan, T. ve Çöğmen, S. (2017). Okula bağl1lık ölçeğinin Türkçeye uyarlanması. Abant İzzet Baysal Üniversitesi Eğitim Fakültesi Dergisi, 17 (4), 1820-1837. https://dergipark.org.tr/tr/download/article-file/379296 adresinden erişilmiştir.

Doll, B., and Hess, R. S. (2001). Through a new lens: Contemporary psychological prespectives on school completion and droping out of high school. School Psychology Quarterly, 16(4), 351-356. doi: 10.1521/scpq.16.4.351.19895

Dupere, V., Dion, E., Nault-Briere, F., Archambault,I., Leventhal, T., and Lesage, A. (2018). Revisiting the link between depression symptoms and high school dropout: Timing of exposure matters. Journal of Adolescent Health, 62, 205211. doi: 10.1016/j.jadohealth.2017.09.024

Enguita, M. F., Martinez, L. M., and Gomez, J. R. (2010). School failure and dropouts in Spain. Barcelona: La Caixa.

Ermish, J., and Francesconi, M. (2001). Family matters: Impacts of family background on educational attainment. Economica, 68(270), 137-156. doi: 10.1111/1468-0335.00239

European Statistical Office. (2020). Early leavers from education and training. Retrieved from https://ec.europa.eu/eurostat/statisticsexplained/index.php/Early_leavers_from_education_and_training

Fall, A. M., and Roberts, G. (2012). High school dropouts: Interactions between social context, self-perceptions, school engagement, and student dropout. Journal of Adolescence, 35(4), 787-798. doi: 10.1016/j.adolescence.2011.11.004

Farah, N., and Upadhyay, M. P. (2017). How are school dropouts related to household characteristics? Analysis of survey data from Bangladesh. Cogent Economics \& Finance, 5, 1-18. doi: 10.1080/23322039.2016.1268746

Field, A., and Hole, G. (2019). Araştırma nasıl tasarlanır ve raporlaştırılır [How to design and report experiments] (A. Özer, Çev. Ed.). Ankara: Anı. (2003)

Finn, J. D. (1989). Withdrawing from school. Review of Educational Research, 59(2), 117-142. doi: $10.2307 / 1170412$

Fisk, B. (1994). Urban school dropouts: A case study. (Unpublished doctoral dissertation). University of Alberta, Alberta. 
Fortin, L., Marcotte, D., Diallo, T., Potvin, P., and Royer, É. (2013). A multidimensional model of school dropout from an 8-year longitudinal study in a general high school population. European Journal of Psychology of Education, 28(2), 563-583. doi: 10.1007/s10212-012-0129-2

Fredricks, J. A., Blumenfeld, P. C., and Paris, A. H. (2004). School engagement: Potential of the concept, state of the evidence. Review of Educational Research, 74(1), 59-109. doi: 10.3102/00346543074001059

Fredricks, J. A., Blumenfeld, P., Friedel, J., and Paris, A. (2005). School engagement. In K. A. Moore and L. H. Lippman (Eds.), What do children need to flourish? New York: Springer.

Gençtanırım, D. ve Ergene, T. (2014). Riskli davranışlar ölçeğinin geliştirilmesi: Geçerlik ve güvenirlik çalışmaları. International Journal of Social Science, 25(1), 125-138. doi: 10.9761/JASSS2304

Gouda, S., and Sekher, T. V. (2014). Factors leading to school dropouts in India: An analysis of national family health survey-3 data. International Journal of Research \& Method in Education, 4(6), 75-83. doi: 10.9790/7388-04637583

Harlow, C. W. (2003). Education and correctional correctional Bureau of Justice statistics (Rapor No. NCJ-195670). Washington: US Department of Justice.

Im, M. H., Hughes, J. N., and West, S. G. (2016). Effect of trajectories of friends' and parents' school involvement on adolescents' engagement and achievement. Journal of Research on Adolescence, 26(4), 963-978. doi: 10.1111/jora.12247

Itzhaki, E., Itzhaky, H., and Yablon, Y. B. (2018). The contribution of parental and societal conditional regard to adjustment of high school dropouts. Journal of Adolescence, 62, 151-161. doi: 10.1016/j.adolescence.2017.11.014

Kessler, R. C., Amminger, G. P., Aguilar-Gaxiola, S., Alonso, J., Lee, S., and Üstün, T. B. (2007). Age onset of mental disorders: A review of recent literature. Current Opinion in Psychiatry, 20(4), 359-364. doi: 10.1097/YCO.0b013e32816ebc8c

Kline, R. (2019). Yapısal eşitlik modellemesinin ilkeleri ve uygulaması[Principles and practice of structural equation modeling]. (S. Şen, Çev. Ed.). İstanbul: Nobel. (2016)

Laird, J., DeBell, M., and Chapman, C. (2006). Dropout rates in the United States: 2004 (NCES 2007-024). U.S. Department of Education. Washington, DC: National Center for Education Statistics. Retrieved from https://files.eric.ed.gov/fulltext/ED494396.pdf

Lansford, J. E., Dodge, K. A., Pettit, G. S., and Bates, J. E. (2016). A public health perspective on school dropout and adult outcomes: A prospective study of risk and protective factors from age 5 to 27 years. Journal of Adolescent Health, 58(6), 652-658. doi: 10.1016/j.jadohealth.2016.01.014 
Magen-Nagar, N., and Shachar, H. (2017). Quality of teaching and dropout risk: A multi-level analysis. Journal of Education for Students Placed at Risk, 22(1), 924. doi: 10.1080/10824669.2016.1242069

Marcoulides, G., and Schumacher, R. (2007). New developments and tecniques in structural equation modeling. London: Lawrence Erlbaum Associates Publishers.

Marphatia, A. A., Reid, A. M., and Yajnik, C. S. (2019). Developmental origins of secondary school dropout in rural India and its differential consequences by sex: A biosocial life-course analysis. International Journal of Educational Development, 66, 8-23. doi: 10.1016/j.ijedudev.2018.12.001

Mikkonen, J., Moustgaard, H., Remes, H., and Martikainen, P. (2018). The population impact of childhood health conditions on dropout from upper-secondary education. The Journal of Pediatrics, 196, 283-290. doi: 10.1016/j.jpeds.2018.01.034

Milli Eğitim Bakanlığı. (2018). Milli eğitim istatistikleri örgün ĕgitim, 2017-18. https://sgb.meb.gov.tr/meb_iys_dosyalar/2018_09/06123056_meb_istatistikleri _orgun_egitim_2017_2018.pdf adresinden erişilmiştir.

Montmarquette, C., Viennot-Briot, N., and Dagenais, M. (2007). Dropout, school performance, and working while in school. The Review of Economics and Statistics, 89(4), 752-760. doi: 10.1162/rest.89.4.752

Mussida, C., Sciulli, D., and Signorelli, M. (2019). Secondary school dropout and work outcomes in tendeveloping countries. Journal of Policy Modeling, 41(4), 547-567. doi: 10.1016/j.jpolmod.2018.06.005

Nakajima, M., Kijima, Y., and Otsuka, K. (2018). Is the learning crisis responsible for school dropout? A longitudinal study of Andhra Pradesh, India. International Journal of Educational Development, 62, 245-253. doi: 10.1016/j.ijedudev.2018.05.006

National Center for Education Statistics. (2015). Common core of data table: Public high school 4-year adjusted cohort graduation rate, by racelethnicity and selected demographics for the United States, the 50 states, and the District of Columbia: School year 2012-13. Retrieved from http://nces.ed.gov/ccd/tables/ACGR_RE_and_characteristics_2012-13.asp

National Center for Education Statistics. (2020). The condition of education 2020 (NCES 2020-144). Retrieved from https://nces.ed.gov/pubs2020/2020144.pdf

Niehaus, K., Rudasill, K. M., and Rakes, C. R. (2012). A longitudinal study of school connectedness and academic outcomes across sixth grade. Journal of School Psychology, 50(4), 443-460. doi: 10.1016/j.jsp.2012.03.002

Orfield, G. (2004). Dropouts in America: Confronting the graduation rate crisis. Cambridge, MA: Harvard Education Press. 
Özdemir, S. (2018). Ergenlik döneminde riskli davranışları önleme ve müdahale. Savi Çakar, F. (Ed.), Yaşam dönemleri ve uyum sorunları içinde (ss. 273-300). Ankara: Pegem.

Özer, A., Gençtanırım, D. ve Ergene, T. (2011). Türk lise öğrencilerinde okul terkinin yordanması: Aracı ve etkileşim değişkenleri ile bir model testi. Education in Science, 36(161), 302-317. https://www.ncbi.nlm.nih.gov/pmc/articles/PMC3192503/pdf/nihms315793.pd f adresinden erişilmiştir.

Ramsdal, G. H., Bergvik, S., and Wynn, R. (2018). Long-term dropout from school and work and mental health in young adults in Norway: A qualitative interviewbased study. Cogent Psychology, 5(1), 1-16. doi: $10.1080 / 23311908.2018 .1455365$

Robison, S., Jaggers, J., Rhodes, J., Blackmon, B. J., and Church, W. (2017). Correlates of educational success: Predictors of school dropout and graduation for urban students in the Deep South. Children and Youth Services Review, 73, 37-46. doi: 10.1016/j.childyouth.2016.11.031

Salmela-Aro, K., Kiuru, N., and Nurmi, J.-E. (2008). The role of educational track in adolescents' school burnout: A longitudinal study. British Journal of Educational Psychology, 78(4), 663-689. doi: 10.1348/000709908X281628

Salmela-Aro, K., Kiuru, N., Leskinen, I. E., and Nurmi, E. (2009). School-burnout 1nventory: Reliability and validity. European Journal of Psychological Assessment. 25(1), 48-57. doi: 10.1027/1015-5759.25.1.48

Salmela-Aro, K., Savolainen, H., and Holopainen, L. (2009). Depressive symptoms and school burnout during adolescence: Evidence from two cross-lagged longitudinal studies. Journal of youth and adolescence, 38(10), 1316-1327. doi: 10.1007/s10964-008-9334-3

Seçer, İ. (2013). Spps ve Lisrel ile pratik veri analizi: Analiz ve raporlaştırma. Ankara: An1.

Seçer, İ., Halmatov, S., Veyis, F. ve Ateş, B. (2013). Okul tükenmişlik ölçeğinin Türk kültürüne uyarlanması: Güvenirlik ve geçerlik çalışması. Turkish Journal of Education, 2(2), 16-27. https://toad.halileksi.net/sites/default/files/pdf/okultukenmislik-olcegi-toad.pdf adresinden erişilmiştir.

Staff, J., and Kreager, D. A. (2008). Too cool for school? Violence, peer status and high school dropout. Social Forces, 87(1), 445-471. doi: 10.1353/sof.0.0068

Stewart, E. B. (2007). Individual and school structural effects on African American high school students' academic achievement. The High School Journal, 91(2), 16-34. doi: 10.1353/hsj.2008.0002

Suh, S., Suh, J., and Houston, I. (2007). Predictors of categorical at risk high school dropouts. Journal of Counseling and Development, 85(2), 196-203. doi: 10.1002/j.1556-6678.2007.tb00463.x 
Sütçü, Z. (2015). Okul terk riski ölçeği’nin geliştirilmesi (Yayımlanmamış yüksek lisans tezi). Gazi Üniversitesi, Eğitim Bilimleri Enstitüsü, Ankara.

Sweeten, G., Shawn D. B., and Raymond, P. (2009). Does dropping out of school mean dropping into delinquency? Criminology, 47(1), 47-91. doi: 10.1111/j.1745-9125.2009.00139.x

Şimşek, H. ve Çöplü, F. (2018). Lise öğrencilerinin riskli davranışlar gösterme düzeyleri ile okula bağlanma düzeyleri arasındaki ilişkinin incelenmesi. Ahi Evran Üniversitesi Sosyal Bilimler Enstitüsü Dergisi, 4(1), 18-30. doi: 10.31592/aeusbed.358223

Tabachnick, B. G., and Fidell, L. S. (2020). Cok değişkenli istatistiklerin kullanımı[Using multivariate statistics] (M. Baloğlu, Çev. Ed.). İstanbul: Nobel. (2013)

Tabuchi, T., Fujihara, S., Shinozaki, T., and Fukuhara, H. (2018). Determinants of high-school dropout: A longitudinal study in a deprived area of Japan. Journal of Epidemiology, 28(11), 458-464. doi: 10.2188/jea.JE20170163

Tang, C., Zhao, L., and Zhao, Z. (2018). Child labor in China. China Economic Review, 51, 149-166. doi: 10.1016/j.chieco.2016.05.006

Tanggaard, L. (2013). An exploration of students' own explanations about dropout in vocational education in a Danish context. Journal of Vocational Education \& Training, 65(3), 422-439. doi: 10.1080/13636820.2013.834956

Thornberry, T. P., Moore, M., and Christenson, R. (1985). The effect of dropping out of high school on subsequent criminal behavior. Criminology, 23(1), 3-18. doi: 10.1111/j.1745-9125.1985.tb00323.x

Townsend, L., Flisher, A. J., and King, G. (2007). A systematic review of the relationship between high school dropout and substance use. Clinical Child and Family Psychology Review, 10(4), 295-317. doi: 10.1007/s10567-007-0023-7

Trampush, J. W., Miller, C. J., Newcorn, J. H., and Halperin, J. M. (2009). The impact of childhood ADHD on dropping out of high school in urban adolescents/young adults. Journal of Attention Disorders, 13(2), 127-136. doi: $10.1177 / 1087054708323040$

Tuominen-Soini, H., and Salmela-Aro, K. (2014). Schoolwork engagement and burnout among Finnish high school students and young adults: Profiles, progressions, and educational outcomes. Developmental psychology, 50(3), 649662. doi: $10.1037 / \mathrm{a} 0033898$

Türkiye İstatistik Kurumu. (2020b). Ortaöğretimde okullaşma oranları, 2012 ve sonrast. https://biruni.tuik.gov.tr/ilgosterge/?locale=tr adresinden erişilmiştir.

Türkiye İstatistik Kurumu. (2020a). Çocuk işgücü anket sonuçlarl, 2019. https://data.tuik.gov.tr/Bulten/Index?p=Child-Labour-Force-Survey-201933807 adresinden erişilmiştir. 
Vaughn, M. G., Salas-Wright, C. P., and Maynard, B. R. (2014). Dropping out of school and chronic disease in the United States. Journal of Public Health, 22(3), 265-270. doi: 10.1007/s10389-014-0615-x

Weybright, E. H., Caldwell, L. L., Xie, H., Wegner, L., and Smith, E. A. (2017). Predicting secondary school dropout among South African adolescents: A survival analysis approach. South African Journal of Education, 37(2), 1-11. doi: 10.15700/saje.v37n2a1353

White, S. W., and Kelly, F. D. (2010). The school counselor's role in school dropout prevention. Journal of Counseling and Development, 88(2), 227-235. doi: 10.1002/j.1556-6678.2010.tb00014.x

Wils, A., Sheehan, P., and Shi, H. (2019). Better secondary schooling outcomes for adolescents in low-and middle-income countries: Projections of cost-effective approaches. Journal of Adolescent Health, 65(1), 25-33. doi: 10.1016/j.jadohealth.2019.03.024

Yorğun, A. (2014). Lise öğrencilerinde okul terki riskinin incelenmesi. (Yayımlanmamış doktora tezi). Hacettepe Üniversitesi, Eğitim Bilimleri Enstitüsü, Ankara.

Zhang, Y., Gan, Y., and Cham, H. (2007). Perfectionism, academic burnout and engagement Chinese college students: A structural equation modeling analysis. Personality and Individual Differences, 43(6), 1529-1540. doi: 10.1016/j.paid.2007.04.010

Zorbaz, O., ve Özer, A. (2020). Okul terk riskini etkileyen öğrenci özellikleri, bir okuldan diğerine farklı midır? Eğitim ve Bilim, 45(202), 191-210. doi: 10.15390/EB.2020.8266 


\title{
Predictors of the School Dropout Risk in Secondary School Students: School Engagement and School Burnout
}

\begin{tabular}{cccc}
\hline ARTICLE TYPE & Received Date & Accepted Date & Published Date \\
Research Article & 01.02 .2020 & 03.29 .2021 & 05.19 .2021 \\
\hline
\end{tabular}

Arif Arslan

Hacettepe University

\begin{abstract}
In this research, the dropout risks of secondary school students were investigated in terms of school engagement, school burnout, and variables obtained from the personal information form. The study is based on the correlational research design. The convenience sampling method was used for determining 420 secondary school students who constitute the sample of the study. $237(56.4 \%)$ out of 420 students are female and $183(43.6 \%)$ are male; and the mean age is 15.4 years. Pearson's Correlation Analysis, Multiple Regression Analysis, and t-test were used for analyzing the data. As a result of the analyses, it was found that there is a significant negative correlation between school dropout risk and school engagement $(r=-.47, p<.05)$; and there is a significant positive correlation between school dropout risk and school burnout $(r=.52, p<$ $.05)$. As a result of the Multiple Regression Analysis, it is seen that school engagement and school burnout explain $35 \%$ of the total variance in the school dropout risk. It has been concluded that the school dropout risk of secondary school students who are male, who previously worked, and who frequently skip school is higher than the students in the other group. As a result, it can be seen that there are many factors affecting the school dropout risk. Taking these conditions into consideration in preventive actions can provide more effective results.
\end{abstract}

Keywords: School dropout risk, early school leaving, school engagement, school burnout, secondary education students.

The Ethical Committee Approval: Since this research was conducted before 01.01.2020, it does not require an ethics committee decision.

${ }^{1}$ Corresponding Author: Res. Assist., Faculty of Education, Department of Educational Sciences, Division of Guidance and Psychological Counseling, e-mail: arif.arslan@ hacettepe.edu.tr, https://orcid.org/00000002-5025-1655 


\section{Purpose and Significance}

Many topics regarding education from the content of the courses to the teaching techniques and from the function of the schools to the status of students in education are discussed in almost every country. One of these issues discussed is the school dropout. Although the definition of school dropout differs according to the countries' educational visions, this situation is considered an important issue by many countries like the United States, India, Italy, Bulgaria, Romania and Turkey. Despite the precautions taken at both international and national levels and scientific research on school dropout, it continues to be an important problem in many countries. (European Statistical Office-EUROSTAT, 2020; National Center for Education Statistics-NCES, 2015).

When the literature is reviewed, it is seen that such variables as low socioeconomic level (Nakajima, Kijima and Otsuka, 2018; Weybright, Caldwell, Xie, Wegner and Smith, 2017; Wils, Sheehan and Shi, 2019), parent's education level (Farah and Upadhyay, 2017; Mussida, Sciulli and Signorelli, 2019), household population (Choudhury, 2006; Farah and Upadhyay, 2017), ethnicity (Cairns, Cairns and Neckerman, 1989; Ermish and Francesconi, 2001), absenteeism (Tabuchi, Fujihara, Shinozaki and Fukuhara, 2018), grade repetition (Fisk, 1994), psychological state (Dupere et al., 2018; Trampush, Miller, Newcorn, and Halperin, 2009), peer relationships (Robison, Jaggers, Rhodes, Blackmon and Church, 2017; Staff and Kreager, 2008; Stewart, 2007), academic achievement, and working out of school (Bridgeland, 2010; Montmarquette, Viennot-Briot and Dagenais, 2007) affect the students' school dropout risk. In addition to these factors, it is seen that school engagement and school burnout variables can also cause negative outcomes in education (Brewster and Bowen, 2004; Salmela-Aro, Kiuru and Nurmi, 2008). It is emphasized that school engagement is an important factor in preventing negative academic outcomes such as school alienation, low academic achievement, and school dropout; and high school students' possibility of graduation increases as a result of increased school engagement (Fall and Roberts, 2012). It is also emphasized in the other studies in the literature that academic performance of the students who have low school engagement in terms of emotional and behavioral aspects during adolescence reduced (Niehaus, Rudasill and Rakes, 2012) and that low emotional and behavioral commitment are significant predictors of school dropout (Im, Hughes and West, 2016). Furthermore, it is seen that there is a significant relationship between school engagement and risky behaviors, and that as the students' school engagement levels increase, their likelihood of engaging in risky behaviors such as antisocial behavior and dropping out of school decreases (Şimşek and Çöplü, 2018). School burnout, on the other hand, is defined as the student's being unable to find the strength to continue activities in the school, being indifferent to school-related activities, and decrease in self-esteem and academic achievement perception (Zhang, Gan and Cham, 2007). The results of the previous studies show that students who experience school burnout are more often absent from school, lack the motivation to perform school-related tasks, and have a higher risk of dropping out of school (Salmela-Aro, Savolainen and 
Holopainen, 2009). As a result, when all these studies in the literature are taken into consideration, it can be said that school dropout behavior, which emerges with the effects of several factors, is the result of a complex process.

School dropout may cause many individual, social and economic problems. For instance, individuals who dropped out of school have a high risk of confronting such serious problems as unemployment or having low-paid jobs (Annabi, 2017; Bjerk, 2012; Campbell, 2015; Doll and Hess, 2001; Mussida, et al., 2019; NCES, 2015; Sweeten, Shawn and Raymond, 2009), committing a crime (Backman, 2017; Harlow, 2003; Itzhaki, Itzhaky and Yablon, 2018; Thornberry, Moore and Christenson, 1985; White and Kelly, 2010), tobacco and alcohol use or drug abuse (Lansford, Dodge, Pettit and Bates, 2016; Townsend, Flisher and King, 2007), and early sexual experience or pregnancy (Fall and Roberts, 2012; Suh, Suh and Houston, 2007; White and Kelly, 2010). Moreover, individuals who dropped out of school are also an important problem for the country's economy. For example, it is estimated that each individual who dropped out of school and does not pay taxes and receives state aid causes a significant loss of 250 thousand dollars in the economy of the United States (NCES, 2015). Considering these negative results caused by school dropout, the importance of studies to prevent this situation and to determine the factors associated with it will be understood. Revealing these relationships will increase the effect of prevention or intervention programs that will be prepared by school counselors within the scope of preventive guidance and psychological counseling services. Moreover, considering that adolescence is the period when risky behaviors are seen the most (Gençtanırım and Ergene, 2014), it was decided to conduct this study with secondary school students. Risky behaviors include many behaviors such as smoking, alcohol and drug abuse, early sexual experience, antisocial behaviors, and school dropout and affect the physical or mental health of the individuals in a negative way (Özdemir, 2018). The adolescence, with which the secondary education level coincides, is a period when the likelihood of the emergence of mental disorders is quite high. As a matter of fact, approximately $50 \%$ of all lifelong mental disorders occur between the ages of 13 and 19 (Kessler et al., 2007). Dropping out of school at secondary education level increases the possibility of individuals' experiencing certain mental disorders (Ramsdal, Bergvik and Wynn, 2018). Therefore, the secondary education level is a critical period for prevention activities to be carried out by school counselors to reduce the possibility of the students' engaging in risky behaviors such as dropping out of school. In this context, this study examined the school dropout risks of secondary school students in terms of school engagement and school burnout variables. Furthermore, it was also aimed to investigate the effects of the variables of gender, household population, class level, family's income, actively working, previous employment, perceived school success, class repetition, having received disciplinary punishment, chronic disease, truancy, and absenteeism on school dropout. 


\section{Method}

This study is a quantitative research and based on correlational research design (Creswell, trans. 2019). The population of the study is secondary school students. The sample of the study consists of 420 secondary school students in total, 237 (56.4\%) female and $183(43.6 \%)$ male, studying at Atatürk Vocational and Technical Anatolian High School, Hamdi Bozbağ Anatolian High School and Mimar Sinan Anatolian High School, located in the city center of Giresun, in the academic year of 2019-2020. While analyzing the data set, t-test, Pearson's Correlation Analysis, and Multiple Regression Analysis were used among parametric tests.

\section{Results}

As a result of the Pearson's Correlation Analysis, it was found that there is a significant negative correlation between school dropout risk and school engagement $(r=-.47, p<.05)$ and a significant positive correlation between school dropout risk and school burnout $(r=.52, p<.05)$. In this sense, it can be said that if the school engagement scores of secondary school students increase, their school dropout risk scores will decrease; and that if the school burnout scores increase, the school dropout risk will also increase. As a result of Multiple Linear Regression Analysis, a significant correlation was found between school engagement and school burnout, and the school dropout risk $\left(R=.59, R^{2}=.35, p<.01\right)$. Accordingly, school engagement and school burnout explain $35 \%$ of the total variance in the school dropout risk. Oneunit increase in the school engagement variable caused a decrease of .36 in the school dropout risk of secondary school students; one-unit increase in the school burnout variable caused an increase of .31 in the school dropout risk of secondary school students.

As a result of the analysis conducted to determine whether there is any difference between the school dropout risks of female and male secondary school students, it was found that the difference between is significant $\left(t_{418}=4.58, p<.05\right)$. According to these results, it can be said that the school dropout risk of male students $(x=2.4)$ is higher than that of female students $(x=2)$. As a result of the analysis conducted to determine whether there is any difference between the school dropout risks of secondary school students who previously worked and have not worked before, it was seen that the difference in between is significant $\left(t_{418}=3.43, p<.05\right)$. It can be said that the school dropout risk $(x=2.4)$ of secondary school students who previously worked is higher than the school dropout risk $(x=2.1)$ of secondary school students who have not worked before. As a result of the analysis conducted to determine whether there is any difference between the school dropout risks of secondary school students with a chronic disease and not having any chronic disease, it was seen that the difference is not significant $\left(t_{418}=-.39, p>.05\right)$. As a result of the analysis conducted to determine whether there is any difference between the school dropout risk of secondary school students who frequently skip school and those who do not skip school, the difference was found to be significant $\left(t_{418}=6.93, p<.05\right)$. According to this result, it can be said that the school dropout risk $(x=3)$ of secondary school 
students who frequently skip school is higher than that of secondary school students who do not skip school $(x=2.1)$. As a result of the analysis conducted to determine whether the school dropout risk of secondary school students differs in terms of the school type variable, it was seen that the difference in between is not significant $\left(t_{418}\right.$ $=-1.84, p>.05)$.

\section{Discussion and Conclusions}

Research findings indicate that the relationship of the school dropout risk of secondary school students with school engagement is negative, and with school burnout significant positive; and it is seen that school engagement and school burnout explain $35 \%$ of the total variance in the school dropout risk. It can be said that these results we obtained support the results of the other studies in the literature. Indeed, as emphasized before, it is seen that school engagement is an important factor in preventing negative academic outcomes such as school alienation, low academic achievement, and school dropout; and high school students' possibility of graduation increases as a result of increased school engagement (Fall and Roberts, 2012). In the study conducted by Im et al. (2016), it is also emphasized that academic performance of the students who have low school engagement in terms of emotional and behavioral aspects during adolescence decreased (Niehaus et al., 2012) and that low emotional and behavioral commitment are significant predictors of school dropout. It is seen that students who experience school burnout are more often absent from school, have less motivation to perform school-related tasks, and have a higher risk of dropping out of school (Salmela-Aro, Savolainen et al., 2009). All these findings obtained regarding school engagement and school burnout are thought to be important in revealing the multidimensional nature of the school dropout risk and for understanding better and preventing school dropout behavior. The findings obtained in this study once again show that school counselors' detecting students with low school engagement and with high school burnout, and preparing intervention programs for these students with the understanding of preventive guidance and psychological counseling can be quite functional in preventing school dropout.

It is seen that different results have been obtained in the studies on the effect of gender on school dropout. Some researchers state that women have a higher school dropout risk (Croninger and Lee, 2001; Mussida, et al., 2019; Nakajima, et al., 2018); while the others state that men have higher school dropout risk (Borgna and Struffolino, 2017; European Statistical Office, 2018; Laird, DeBell and Chapman, 2006; Yorğun, 2014). However, in some studies, it is seen that gender is not a significant predictor of school dropout (Özer, Gençtanırım and Ergene, 2011; Zorbaz and Özer, 2020). When the schooling rates of female students at the secondary education level in the city of Giresun are examined, it is seen that the rate was $89 \%$ in 2018 and around $93 \%$ in 2019 . When compared to the previous year, it is noteworthy that there is a significant increase in the schooling rate of female students at secondary education level. In Turkey, the city of Rize has the highest schooling rate in girls at secondary education level with $98 \%$; nevertheless, this rate is around $53 \%$ in Muş 
(Türkiye İstatistik Kurumu, 2020). These data also show that regional differences may have an influence over school dropout risk and schooling rates. As a matter of fact, attaining different results in studies examining the school dropout risk by gender may be due to the characteristics of the sample group.

One of the findings obtained in the study is that the school dropout risk of the students who previously worked is higher than the students who have not worked before. The results attained bear similarity to the literature (Bridgeland, 2010, Montmarquette, et al., 2007). As a matter of fact, having worked before may cause a decrease in academic success and school engagement of the students, and result in dropping out of school at the end of this entire process. In this study, it has been concluded that the students who frequently skip school have a higher risk of dropping out of school. When the literature is reviewed, it is seen that the variables of truantry and absenteeism are important factors affecting school dropout (Balfanz, Herzog and Iver, 2007; Enguita, Martinez and Gomez, 2010; Finn, 1989; Fortin, Marcotte, Diallo, Potvin and Royer, 2013; Orfield, 2004). Accordingly, it can be said that this finding is consistent with the literature. As a result, it can be said that the school dropout risk is affected by many factors and studies on these factors are of great importance to prevent the school dropout risk.

\section{The Ethical Committee Approval}

Since this research was conducted before 01.01.2020, it does not require an ethics committee decision. 